Intermedia International e-Journal, Fall -December - 2017 4(7)

*DOI NO: 10.21645/intermedia.2017.39 *Submit Date: 22.04.2017～*Acceptance Date: 28.11.2017 *ISSN: 2149-3669

\title{
Hz. Muhammed: Allah'ın Elçisi Filminin Mecidi Sineması Bağlamında Analizi
}

\author{
An Analysis of The Movie "Muhammad: \\ The Messenger of God" In The Context of Majidi Cinema
}

\author{
Hatice GÖKÇE* \\ İstanbul Ticaret Üniversitesi \\ Uygulamalı Sosyoloji Lisansüstü Öğrencisi \\ İstanbul
}

\begin{abstract}
Özet: Mecid Mecidi'nin kendine has bir sinema dili olduğu söylenebilir. Bilhassa çocuklar ve kadınlar üzerinden fıtrat temelinde kurguladığı karakterler doğunun mistik öyküleri içinden, estetik bir sanat diliyle beyaz perdede hayat bulur ve yaradıışla çelişmeyen "fıtrat sineması" olarak tanımlanır. Mecidi ve sineması bu nedenle Doğunun mümessili olarak kabul edilir. Bu çalışmada; kültürel bir çalışma alanı olarak genelde sinema, özelde İranlı yönetmen Mecid Mecidi sinemasının yeni ve özgün bir dil kurduğu önkabulüyle bir tahlil yapılmaya çalışılmıştır. Bu bağlamda Mecidi'nin son filmi Hz Muhammed'de özgün dilini muhafaza etmekle birlikte; batıya mesaj verme kaygısının teknik, müzik ve görsel açılardan özgünlüğünü Hollywood lehine yitirdiği gibi eleştirilere, literatür taraması ve Mecidi'nin filmleri üzerinden cevap aranacaktır. Kültür çalışmaları bağlamında sinemaya bakıldığında imgesel ve belgesel sinemanın dönüşerek mevcut teknolojiyi kullanmasının, Üçüncü Sinemaya olan etkileri; yeni tanımlar ve kavramların içinde Mecidi Sinemasının da bu dönüşümden ne ölçüde etkilendiği; teknoloji ile birlikte Mecidi'nin "fıtratın dili" ile sinema yaptığı iddiasının kısmen film endüstrisi ve bu endüstrinin baş temsilcisi Hollywood lehine zayıfladığı eleştirileri; Mecidi ve Üçüncü Sinema'nın kavramsal benzerlik ve ayrışımları; Hz. Muhammed: Allah'ın Elçisi filminin Mecidi Sinemasındaki yeri gibi temel soru ve sorunlar çalışmanın zeminini oluşturacaktır.
\end{abstract}

Anahtar Kelimeler: Fıtrat Sineması; Ü̧̧üncü Sinema; Hollywood Sineması; Yeni Gerçeklik

"We can only see what isn't there or in other words meaning, and importance of absence." Peter Burke

Extended Abstract: What makes Majid Majidi's cinema unique is that most particularly the characters which he articulates based on the disposition through children and women that animate in the my stics stories of the east with an aesthetic art language and is defined as "disposition cinema" which doesn't conflict with then ature.

In this study; an attempt has been made to carry out an analysis with a premise that cinema as a cultural workplace in general and particularly the Iranian director Majid Majidi's cinema has established a new and original language. In this context, an answer to the criticism such as the last film "Muhammad: The Messenger of God" of Mecidipreserved the original language in social content but it lost its originality in technical, musical and visual aspects with the concern of giving messages to the West in favor of Hollywood; whether the defiance of the unique to the popularity is an obligation or preference will be sought by a literary scan and through the films of Majidi.

*htc_gokce@hotmail.com 
The local paradigm that renders Majid Majidi's cinema unique such as the fact that he has chosen cinema as the place toutter the universal one and conveying social problems to the cinema with a poetic language are his features that make him there presentative of the East. Particularly the characters that he articulates on the basis of disposition through children and women animate through the mysticstories of the east on the white screen with an aesthetic art language. This cinema described as "disposition cinema" which doesn't conflict with then ature is not only presented through scenario, fiction orcharacters, but also in the Wisdom of the East ${ }^{1}$ as technical, musical and production.

"Third cinema" in which Majidi's cinema is defined as well is described on thegrounds of anti-imperialist, anticapitalist, militan, politic, criticaland "other"notions. These definitions, whether Majidi'scinema is the third world's cinema and per say the "third cinema" description it self are still a question of debate.

In this research that is conducted by using qualitative research methods, the cinema will be examined by using literature search method and meaningful results thats upport there search shall be sought by interpreting Majidi's movies.

Considering cinematography in the context of cultural studies, basic questions and problems such as the effects of imaginary and documentary cinema transforming existing technology on the Third Cinema; the extent to which Mecidi cinema is influenced by this transformation in new definitions and concepts; criticism that Mecidi created a cinema with "the language of disposition" and technology is weakening in part in favor of the film industry and its main representative Hollywood; conceptual similarities and differences of the Mecidi's and Third Cinema; the place of "Hz. Muhammad: The Messenger of Allah"in the Mecidi Cinemawill create the basis of this research.

The important point that needs to be considered here is that the Third Cinema is used as a classification and evaluation criteria, being a "marginalizing" concept, disregarding the geographical, cultural and social differences by means of evaluating the countries with in this conceptunder an imaginary and deceptive roof are criticized.

Queries such as the senotions based on this political rhetoric, whether the "orientalism" has an effect on the fact that Iranian Cinema was accepted internationally; globalization's dangerous but also liberating effects as Dabaşi mentioned shall be handled in another research. In that sense, it's considered useful to regard these points in another research that will be conducted in thefuture.

Not being able to deepen in this study due to the lack of philosophica land sociological studies except the movie reviews on Majidi's movies, the short duration of time of its completion can be counted as the constraints in this study. When all these evaluations and comments are done, th efact that this research will be insufficient and cause and effect relation shall not be concluded from it should be remembered. However, the subject can be deepened with the obtained clues by searching English and Farsi literature. In addition to this, obtaine dfinding sare important in sense of developing an uniquelanguage in thecinemaanddrawingattentiontotheimportance of thecinema in culturalstudies. When these constraints including the factthat this isn't a sufficient study due to time limit as remarked are considered, considering the results obtained from this research as sufficient shall not be an accurate approach.

Key Words: Disposition Cinema; Third Cinema; Hollywood Cinema; Neorealism

\section{Giriş}

Mecid Mecidi'nin sinemasını kendine has kılan, yerel paradigma ile evrensel söz söyleme alanı olarak sinemayı seçmiş olması ve sosyal sorunları sinemaya şiirsel dille aktarması gibi; onu Doğunun mümessili konumuna getiren özellikleridir. Bilhassa çocuklar ve kadınlar üzerinden fıtrat temelinde kurguladığı karakterler, doğunun mistik öyküleri içinden, estetik bir sanat diliyle beyaz perdede hayat bulur. Bu "fıtrat sineması" olarak

${ }^{1}$ Nazan Bekiroğlu defines this language as "the language of the state in the wisdom of the East" in "Baran: Language of the Disposition" (Bekiroğlu, 2010). 
tanımlanan yaradılışla çelişmeyen sinema; sadece senaryo, kurgu ya da karakterler üzerinden değil, teknik, mekân, müzik ve prodüksiyon olarak da halin dili Şarkın bilgeliğinde ${ }^{2}$ sunulur.

Mecidi'nin sinemasının da içinde tanımlandığı "üçüncü sinema" reaksiyoner, bağımsız, antiemperyalist, antikapitalist, militan, politik, eleştirel ve “öteki” gibi kavramlar zemininde tanımlanır. Bu tanımlamalar da, Mecidi'nin sinemasının üçüncü dünya sineması olup olmadığı da, bizatihi “üçüncü sinema” tanımının kendisi de tartışılmaya devam etmektedir.

Bu çalışmada; kültürel bir çalışma alanı olarak genelde sinema özelde İranlı yönetmen Mecid Mecidi sinemasının yeni ve özgün bir dil kurduğu ve son filmi $\mathrm{Hz}$ Muhammed'de sosyal içerikte özgün dilini muhafaza etmekle birlikte, batıya mesaj verme kaygısının teknik, müzik ve görsel açılardan özgünlügünü Hollywood lehine yitirdiği; özgün olanın popülariteye yenilgisinin zaruret mi, tercih mi olduğu gibi sorulara cevap aranmaya çalışılacaktır.

Mecidi'nin son filmi Hz. Muhammed: Allah'ın Elçisi özellikle dînî ve kültürel kodlar üzerinden ülkemizde çokça tartışılmış, medyada geniş yer almıştır. Kendi alanı üzerinden, yani sinema zeminindeki eleştiri ve yorumlar ise bahsi geçen tartışmaların gölgesinde, kısır ve yavan kalmıştır. Bu anlamda kuramsal ve kavramsal çerçevede bir çalışma yapmanın hem bir ihtiyaç hem de Mecidi'ye hakkı teslim eden eleştiri olarak borç kabul edilmesi, bu makalenin motivasyonu olmuştur.

Sinemanın kültürel bir alan olarak sosyolojinin ilgi alanına girdiği, aynı zamanda da sinemanın sosyolojiyi dikkate almadan ontolojik ve epistemolojik zeminini oluşturamayacağı söylenebilir. Topluma söz söylemenin bir aracı kabul edilen sinema ise gerek nitel gerekse nicel pek çok başlık ve içerikle bilimsel çalışmaların aktörü olmuştur. Hal böyleyken toplumsal olanda sinemanın, sinemada da toplumsal olanın girift sorunları, kodları ve anlamlandırmaları akademik çalışmaların konusu olmaya devam etmektedir.

Bu çalışmada ayrıca;

- Mecidi filmleri üzerine film eleştirileri hariç felsefî ve sosyolojik çalışmaların nitelik ve nicelik olarak yetersizliği,

- Kuramsal çalışmaların oryantalist perspektifle kavramlaştırdığı sinema akımlarının tartışımaya devam etmesi,

- Mecidi'nin son filmi “Hz. Muhammed: Allah'ın Elçisi”nin din, mezhep ve siyasî tartışmalardan sıyrılıp hakiki mecrasında tartışılamamış olması,

- Farsça literatürün taranamaması,

- Tamamlanma süresinin kısalığı nedeniyle derinleşilememesi gibi hususlar çalışmadaki kısıtılıklar arasında sayılabilir.

\section{Kültür Çalışmaları Bağlamında Sinemaya Bakış}

Çayan Özvaran edebiyat ve sanat dergisi olan Karabatak'ta sinemayı tarif ederken anlatım dilini tiyatro metinlerinden aldığını kabul etmekle birlikte, sinemanın hiçbir zaman edebiyat kadar doğurgan bir dile ulaşamayacağını ifade ediyor. Özvaran sinemanın yapı bakımından edebî bir metin olmasının imkânsızlığına vurgu yaparken, diğer yandan edebiyatçıların da alelâde bir uğraş gibi oturup yazabileceği bir metin olmadığını; bileşiminde kelimeler ve teknik, imge ve somut, hayal gücü ve imkân dairesinin bulunduğunu da ekliyor (Özvaran, 2015, s. 85). Aristo'nun seyirlik sanatı doğayı ve doğalı "taklit" olarak tanımladığı ünlü eseri Poetika'nın sinemaya dair açıklamalarda yer alması isabet olacaktır:

2 "Baran: Fıtratın Dili" denemesinde Nazan Bekiroğlu bu dil için "Şarkın bilgeliğinde halin dili" tanımını yapıyor (Bekiroğlu, 2010). 


\begin{abstract}
"Taklit, daha çocukluktan başlayarak insanın doğasında vardır; 'öteki' hayvanlardan, taklide duyduğu büyük eğilimle ayrılır insanoğlu ve ilk bilgilerini taklit yoluyla edinir; taklitten büyük bir haz alır. Bunun açık bir kanıtı, gerçekte çok zor seyredebileceğimiz şeylerin, örneğin en korkunç canavar görüntülerinin ya da kadavraların birebir taklidinden bile çok hoşlanmamızdır. Bunun nedeniyse, öğrenmenin çok hoş bir şey olmasıdır: yalnızca felsefeciler için değil -ortak çok yanları olmasa da- tüm insanlar için. Resimlere bakmaktan hoşlanırız, çünkü onlara bakarken öğrenebiliriz, akıl yürütebiliriz ve örneğin şu resimden, onun falanca kişiyi betimlediği sonucunu çıkarabiliriz. O adamı daha önce görmediysek bile yapıt, bu kez taklit olarak değil, yapılışındaki ustalıkla, renkleriyle ya da başka bir özelliğiyle hoşumuza gidecektir."(Aristotales, 2011, s. 13).
\end{abstract}

Bir imge olarak sanat eserini seyreden izleyici, doğrudan doğruya imgenin dünyası ile mi karşı karşıyadır? İmge kendisini bir iz olarak geride bırakan varoluşa / dünyaya açılan, onu gösteren şeffaf bir cam mıdır (Olgun, 2008)? Bu sorgulamaların çerçevesinde genelde sanat, özelde sinema ve içinde bulunduğu medya iletişim eleştirilerini, kültür çalışmaları bağlamında gözden geçirmek gerekir.

Kültürel tüketim nesnesi olarak sinemaya geçmeden kültürel tüketim / kültür endüstrisi gibi kavramlar irdelenerek başlanabilir. Ingiliz Kültürel Çalışmalar içerisinde pek çok gelenek kültürel tüketim meselesini çalışmış olsa da, bu odağın açık bir şekilde adının konması tarihi yeni sayılır (Turner, 2016, s. 198). Eleştirel Teori'nin kuramcılarından Frankfurt Okulu Güdüp Yönetme Kuramı'nda sanatın ütopik ve kitle kültürünün güdüp yöneten ${ }^{3}$ yanını kuramsallaştırdığını dile getiren Özbek, geçmiş dönemdeki büyük sanat eserlerinin hakikilik içeriğini koruyabilmesini birey ve toplum arasındaki boşluğu ödünvermez biçimde ifade etmelerine bağlar. Ekonomik gereksinim ile içsel (hakikilik) gereksinimin uyuşmayacağını da vurgulayarak bu eğlence

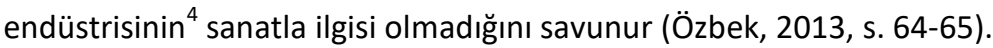

"Adorno 'Kültür Endüstrisi' kavramını Nazizm sona ererken ortaya atar (1944). Yıllar sonra bu kavrama geri dönerek 'Kültür Endüstrisine Genel Bir Bakış' makalesini yazar (1963). Bu arada "Kültür ve Yönetim" üzerine düşüncelerini de yayınlamıştır (1960). Bu kitapta derlenen yukarıdaki üç yazı, gerek kültür kuramı, gerekse kültürel hayatın dönüşümü konusundaki eleştirel çalışmaların vazgeçilmez kaynaklarını oluşturur. 19. yüzyılda, Endüstri Devrimi'nin akılcılığına karşıt bir anlamda tanımlanan sanatın nasıl giderek maddi üretim süreçlerine ve onları yöneten akla yenik düştügünü anlatırlar. Endüstriyel mantığın ve bürokratik işletme disiplinlerinin denetimine giren modern sanatın özerkliğini ve eleştirelliğini yitirmesini incelerler. Adorno'nun düşüncelerinin ufkunda, kültür ve sanat yönetiminin zamanımızdaki baş döndürücü yükselişini izleriz. Adorno kültür endüstrisinin gidişatını da, yol açtığı tehdidi de açıkça görmüştür. En kötümser tahminlerinin zamanla gerçekleşmesi, kültür endüstrisi üzerine yazdıklarının, rahatsız edici de olsa, ne kadar çağdaş olduğunu gösterir. J.M. Bernstein" (Adorno, 2016).

Güdüp yönetme kuramını yanlış bilinçlilik kuramı olarak eleştiren ilk ve en önemli yazılardan biri 1970 yılında $H$. M. Enzensberger'e aittir. Enzensberger, kitle kültürünün insanlara sol düşünürlerin savunduğu gibi salt yanlış bilinçlilik ve yanlış ihtiyaçlar dayatmadığını, çünkü kitle kültürünün stratejilerinin aslında gerçek ihtiyaçlara cevap vererek başarılı olmak üzerine konumlandığını savunur. Öyle olmakla birlikte gerçek ihtiyaçların yine de bilinç endüstrisi tarafından manipüle ettiğini de kabul eder (Özbek, 2013, s. 71).

Francesko Casetti geleneksel sinema tarihi çalışmalarının, sinema gibi yeni ortaya çıkan bir fenomeni değerlendirirken, sanat ya da edebiyat tarihine fazlaca yaklaştığını bu yüzden de artık geçerliliği olmayan

${ }^{3}$ Güdüp yönetme (manipulation), "etimolojik olarak biçimlendirme, becerme, kafadaki belirli bir amaçla belirli bir materyalin teknik işlemlere tabi tutulması demektir. Teknik nitelikteki bir müdahale kendisi ile zamanca yakın (inmediate) bir toplumsal sonuç yaratırsa, bu durumda, güdüp yönetme siyasal bir edim olmaktadır. iletişim araçları endüstrisinde, tanımı gereği, budur." (Enzensberger, 1980, s. 22)

4 Hakikilik, yenilik ve başka bir dünya (ütopya) tasarımına izin veren eleştirel mesafenin (negativity), kültür endüstrisi ürünleriyle ilgisi yoktur (Horkheimer, 1941) (Özbek, 2013). 
açıklama çerçevelerine bağı kaldığını belirtir. Sinemanın içerik ve üslûp olarak beslendiği edebiyat ve tiyatronun zemini olsa da, teknik anlamda 1826'da Fransız mucit Joseph Niepce'nin ilk tarihte bilinen ilk fotoğrafı çekmeyi başarması en önemli evrelerden biridir(Özen, 2009). 1877 yılına geldiğimizde ise Edward Muybriagef, eşit ve kısa aralıklarla yan yana dizdiği 24 fotoğraf makinesiyle koşan bir atın görüntülerini çeker ve bu fotoğraflarla ilk hareketli görüntüyü elde eder. Böylece artık sinema geri dönüşü olmayan bir sürecin ve beraberinde pek çok sosyolojik, felsefi, sanatsal, kültürel vb. tartışmanın aktörü olarak hayatımıza girer. Thomas Alva Edison ve yardımcısı William Laurie Dickson'un 1890'da ilk kamera diyebileceğimiz kinetograf ardından kinetoskop ve daha sonra gelişmiş haliyle vitaskop gösterim makinesi ilk sinemaskop kilometre taşlarını oluşturur ${ }^{5}$. 1893 yılına gelindiğinde ise tekerlek üzerinde hareket ettirilebilen ilk film stüdyosunu da Edison kurmuş olur. Bu stüdyo yukarıda da sözü geçen tiyatro zemini teknikle buluşturması hasebiyle Kinetografik Theater olarak şöhret bulur (Tatar, 2012).

\begin{abstract}
"Modernleşme, pek çok yazarın vurguladığı gibi, şehir hayatı ile ilgili bir olgudur. Sinema, bu olgunun görünür ve deneyimlenebilir temel bir bileşeni gibidir.

Nasıl şehir, çeşitli ulaşım araçları, sokakları ve meydanlarıyla tesadüfi karşılaşmalar yaratıp, aynı şehri paylaşan şehirlileri benzer duygulara sahip tedirgin hemşeriler haline getirdiyse, sinema da seyircisini dünyanın başka yerlerine götürüp, bir yandan diğerlerinin kendisinden ne kadar farklı, öte yandan ne kadar aynı olduğunu göstermekteydi. Hatta farklı olanları aynılar konusunda sinema, benzersiz bir güce sahiptir." (Kaynar, 2012, s. 147).
\end{abstract}

Günümüze gelindiğinde sinemanın son yüz yılda baş aktörlerinden ve popüler kültür üreticisi olarak sinemanın temsilcisi Hollywood olmuştur. Hollywood sineması üzerine olan tartışmalarda bir yandan film arşivlerinde unutulmaya yüz tutmuş filmler ortaya çıkarılır, bir yandan geleneksel sinema tarihinin dönemlendirmeleri üzerinden yoğun tartışmalar gündeme getirilmeye başlanır. Örneğin Bordwell, Thompson, Staiger üçlüsünün, Amerikan sinemasının 1917 öncesi dönemini, klasik-öncesi dönem ve 1917'den 1960'a kadar olan dönemi ise "Klasik Hoolywood Sineması" olarak tanımlamaları; film tarihçisi Tom Gunning'in, geleneksel sinema tarihçilerinin ilkel sinema olarak önemsiz bulduğu 1907 öncesi dönemle ilgilenmesi ve bu dönemi atraksiyonlar sineması (cinema of attractions) olarak adlandırması, söz konusu dönemselleştirme tartışmalarının başlıcaları olur. Hollywood'un bir "Rüya Fabrikası” olarak küresel siyasetin, siyasî ve kültürel hegemonyanın üreticisi olduğunu ${ }^{6}$ söylemek mümkündür.

Batılı, büyük, egemen Hollywood anlatısının karşısında direnmeye çalışan ve kendisine yaşam alanı arayan minimal, Doğulu ve alternatif bir sinemanın varoluş koşullarına ve karşıtlığına odaklanarak İran Yeni Dalga Sineması'nı ele alan Serpil Kırel “İran'da Sinema: İran Sineması ve Üretim Dinamikleri ve Anlatıya Etkileri Üzerine Bir Değerlendirme" adında bir makale kaleme almıştır (Esra Biryıldız, 2007). “Üçüncü Sinema”yı Fernando Solanas ve Octavio Getino "Üçüncü Sinema'ya Doğru" adını verdikleri manifestolarında tanımlarlar (Odabaş, 2013, s. 16). Dünya ölçeğinde bir sinema olmakla birlikte bütün dünya sinemalarını egemenliği altına alan Hollywood ya da Amerikan Sineması, manifestoda Birinci Sinema olarak tanımlanır. İdeolojinin yaratıcısı olarak değil, ideolojinin tüketicisi olarak Solanas ve Getino'nun Birinci Sinema'nın "seyirci"si olan pasif ve edilgin insanı; Frankfurt Okulu’nun “Güdüp Yönetme Kuramı”nı hatırlatır. Ikinci Sinema ise manifestoda dünyanın birkaç ülkesinde ortaya çıkmış sinema ve akım hareketleri olarak, egemen sinema anlayışına tepki

${ }^{5}$ Edison ve yardımcısı Dickson; 15 metrelik filmler üzerine kırk görüntü kaydedebilen kinetograf geliştirilerek kaydedilen bu görüntülerin seyredilebileceği kinetoskop geliştirildi. Büyük ve gizemli bir kutu görünümündeki kineteskop, izleyicini gözlerini kutunun üzerindeki iki küçük deliğe dayayarak izleyebilmesi haliyle kişiye sinema gibiydi. Edison ve Dickson bu sorunu vitaskopla çözdü.

${ }^{6}$ Gramsci'nin hegemonya kavramı (ve kuramı) medyaya uygulandığında görülür ki medya, okuyuculara/izleyicilere/dinleyicilere egemen sınıfın değerlerini aktaran bir araçtır. Medya genel olarak egemen yapıya ve egemen değerlere karşı olan ve bunları tehlikeye atan her türlü olaya karşıdır.Sonuç olarak medya egemen değerleri aktararak hegemonyayı yeniden üretir. 
anlamında ortaya çıkmış alternatif sinemalardır. Buna rağmen sistemin içinde kalarak film yaptıkları ve dolayısıyla sisteme entegre olarak daha ileriye gidemedikleri, yetersiz kaldıkları gibi eleştirilerden nasibini almıştır. Amerikan Bağımsız Sineması da bu grupta yer alır. "ifade sineması", "Fransız yeni dalgası", "yeni sinema" ikinci Sinema olarak sayılabilecek örneklerdir. Michael Chanan nihilist, karamsar ve gizemli olarak tanımladığı ikinci Sinema'nın orta sınıfın ve küçük burjuvazinin özlemlerini dile getirdiğini söyler (Odabaş, 2013, s. 20).Üçüncü Sinema bütün bunların sonucunda sadece Birinci Sinema'ya değil, ikinci Sinema'ya da karşı olarak konumlanmıştır denilebilir. Üçüncü Sinemacılar sömürgeciliğe ve yeni sömürgeciliğe karşıdırlar. Manifestoda sömürgeciliğe film yapmak donkişotluk olarak anlamlandırılır. Solanas "Kamera, görüntü-silahlarının yorulmak bilmez alıcısıdır; projektör, saniyede 24 kare ateş edebilen bir silahtır." tanımıyla Üçüncü Sinemacıların kamerayı sinemada nasıl konumlandırdığını ifade eder aslında... (Odabaş, 2013, s. 25)

İmgesel ve belgesel sinemanın dönüşerek mevcut teknolojiyi kullanması, Üçüncü Sinemayı da etkilemektedir. Değişen Üçüncü Sinema'nın teknolojiyi kullanarak ayrışmış halini özgün tanımından ayırmak için Post-Üçüncü Sinema ya da íkinci Kuşak Üçüncü Sinema tanımlamaları kullanılmaktadır (Odabaş, 2013, s. 32).

Bu anlamda değinilmesi gereken "İran Sineması"nın bütün bu tanımların içinde nereye oturduğuna ise, Hamit Dabaşi'nin "Iran Sineması" kitabına değinilerek cevap araranacaktır. Dabaşi "iran sineması, en iyi ihtimalle, iran politikasının jeo-merkezciliğini aşıp geçen Kopernikusçu bir heliyosentrizmi ifade eder." derken İran sinemasının en iyi örneklerinde güncelin ve zamanın ötesinde filmlerin yapıldığını vurgular (Dabaşi H. , 2013 (2004), s. 301)

\section{Mecidi ve Üçüncü Sinema}

Egemen sinema dilinin ve unsurlarının dışında farklı bir dil kurduğu, merkezin dışından ve merkezin dışındakilere kamera tuttuğu iddia edilen Üçüncü Sinema ${ }^{8}$; üzerine yazılan, çizilen bir akım olarak dikkati çekmektedir. İtalyan Yenigerçekliği'nden ${ }^{9}$ etkilendiği kabul edilmekle birlikte; artık ne Üçüncü Sinema ne de Post-Üçüncü Sinema bu son dönem İran ve Mecidi Sineması'nı kavramsallaştırmada yeterli ve masum olmayabilir. Yeni İran Sineması'nın bu bağlamda daha doğru bir tanım olduğu söylenebilir. Mecidi bu anlamda bu çalışmanın örneklemini oluşturmaktadır.

\footnotetext{
${ }^{7}$ Kopernik, dünyanın ve diğer gezegenlerin güneş etrafında döndükleri kuralını açıklamıştır. Heliosentrik (gün ya da güneş merkezcilik) teori bugün Kopernik teorisi olarak da adlandırılır. (Biraz da Felsefe)

${ }^{8} 1950$ 'lerden başlayarak giderek şiddetlenen isyanlar ve ülkemizin yakından bildiği "Tam Bağımsızlık" hareketleri dünyanın üçte birinin en tartışmalı sloganı haline gelmişti. Bu ülkelerde mücadeleye koşut olarak güçlü ve etkili bir sinema doğdu, bu sinemaya genel olarak Üçüncü Dünya Sineması adı verildi. Üçüncü Sinema, bize göre, bu mücadelenin içindeki, zamanımızın en büyük kültürel, bilimsel ve sanatsal manifestosunu yazmaktadır, yani başlangıç noktası olarak her insanla özgür bir kişilik yaratma olasılığını, kültürün sömürgeciliğin-egemenliğinden-kurtarılmasını kendine hedef koyan ve bunun için mücadele eden sinemadır. Bu yaklaşım içinde olan 20'den fazla ülkede ulusal sinema inşa edilmeye çalışıldı, batıda ilgiyle karşılandı, ancak kendi ülkelerinde siyasî iktidarın yoğun baskısıyla karşılaştılar, bu nedenle daha doğuşundan militan ve yeraltı sineması oldu. (Armes, 2011, s. 2)

${ }^{9}$ Yenigerçekçilik: İkinci Dünya Savaşı ertesinde İtalya'da ortaya çıkan ve nesnel olmayı, gündelik gerçeklikleri toplumsal bağlamları çerçevesinde gözlemlemeyi amaçlayan sinema akımı. (Bağdatlı, 2000)
} 

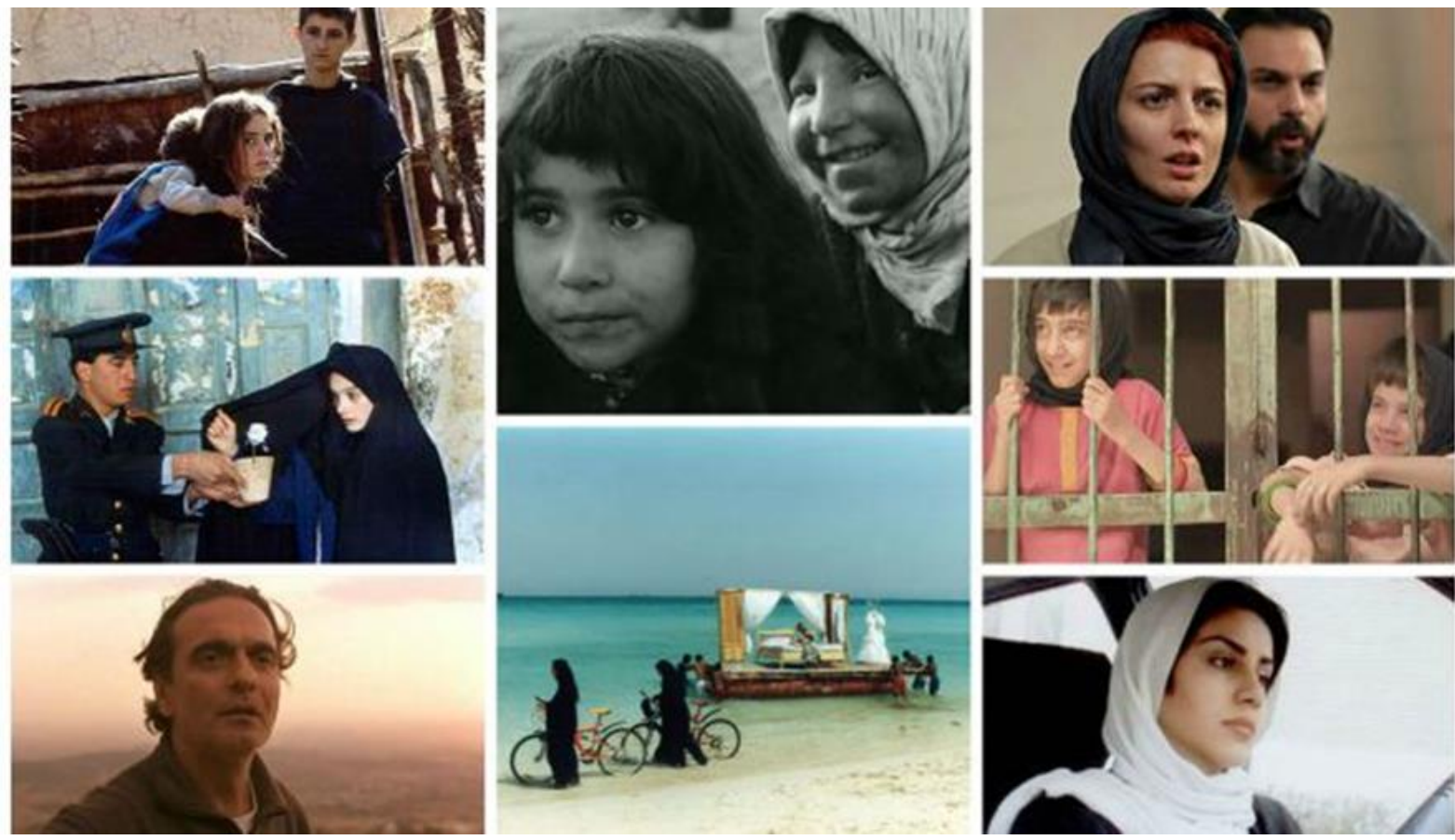

Görsel 1: Üçüncü sinema olarak tanımlanan ötekinin / kadının sesi İran sineması...

(İran Sineması'na Giriş: En Özel 15 İran Filmi, 2014)

Üçüncü sinemanın önemli unsuru kadınlardır. "Kadın karakterlerin sosyal hayattaki rolü ne kadar önemliyse filmlerdeki konumu ve anlamı da o kadar büyük önem arz etmektedir... Sinemanın yapıldığı her coğrafyada kadın karakterler ataerkil düzen içerisinde stereotipleştirilerek betimlenmektedir."(Film Arası, 2016, s. 18)

Mecid Mecidi'nin kendine has yerel paradigma ile evrensel söz söyleme alanı olarak sinema ve sinemaya şiirsel dille sosyal sorunların serzenişini söyletmesi; onu doğunun mümessili konumuna getirmiştir. Daha çok çocuklar ve kadınlar üzerinden fitrat temelinde kurguladığı karakterler, doğunun mistik öyküleri içinden, estetik bir sanat diliyle hayat bulur kamera önünde...



Görsel 2: "Cennetin Çocukları" filminden bir sahne... (İran Sineması'na Giriş: En Özel 15 İran Filmi, 2014) 
Bir röportajında insan fıtratının diliyle yapılacak filmlerin insanlığın gönüllerini fethedeceğini söyleyen Mecidi'nin önemli filmlerinden olan Cennet Çocukları (1997), tam anlamıyla bu fitratın içine nüfuz etmeye ve orada bulduğu güzellikleri ortaya çıkarmaya çalışır. Kız kardeşinin ayakkabısını tamirden aldıktan sonra kaybeden ve bundan dolayı derin ve samimi bir acı duyan Ali ile kız kardeşi Zehra filmin odağındaki "cennet çocukları"dırlar. Cennet çocuklarıdırlar, çünkü insan tabiatının "henüz" bozulmamış ve saf hâlini temsil ediyorlardır.

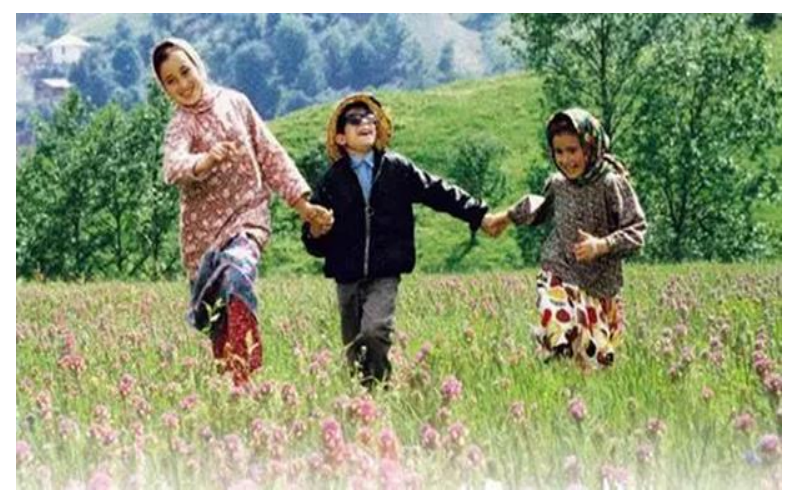

Görsel 3: "Cennetin Rengi" filminden bir sahne... (İran Sineması'na Giriş: En Özel 15 İran Filmi, 2014)

Söğüt Ağacı filmi, daha önce Cennetin Rengi (1999) filminde de işlenen "görmemek" konusu üzerine bir tartışmadır. Görmenin gerçek organının göz olup olmadığı; ya da gözün tek başına görmek için yeterli olup olmadığı üzerine düşündüren yine Doğu’ya ait bir tefekkür çabası vardır. Söğüt Ağacı birç̧ok açıdan çok derin bir tefekkür filmidir. Insanoğlunun labirentlerinde dolaşarak onun fitratına ulaşmak gerçekten çok zor bir yolculuktur. Mecidi bu filminde de bu yolculuğu amaçlamıştır. Hakiki hayat için verdiği sözü unutarak gölge hayatında kaybettiklerinin izine düşmüş ve bunu isyan vesilesi yapmış bir insanın hikâyesidir söz konusu olan. Bütün insanlar gibi Yusuf da bu ağır sınavda büyük bir bocalama geçirir.

Bir başka örnek Baran (2001) filminde ise, İran'da kadın olmanın, yabancı bir kadın olmanın ağırlığı izleyicinin üzerine çöker. Erkekler de bu ağırlığın altında ezilmektedir.

Mecidi bütün filmlerinde fıtratın dilini konuşturduğunu iddia eder. Ona göre fıtratın dili Kur’an'ın özünden beslenir.

"Mecidi, filmlerini yaparken Kur'an'ın dilini örnek aldığını ve insan fıtratını konuşturmaya çalıştığını ifade eder. Nedir Kur'an'ın dili? Şurasını iyi bilmemiz gerekir ki Kur'an, bütün sanat eserlerini ve bütün ilmi eserleri kapsayıcı bir enginliğe sahiptir; hepsine yol gösterici olmuştur ve olmaya da devam edecektir. Mecidi'nin, hayatı bütün gerçekçiliğiyle beyaz perdeye aktarması, onun eserlerine hem insani hem de islâmi bir kimlik katıyor. Esasında bu ikisi bir değil midir? Kur'an-ı Kerim insan hakkında ne demişse, en büyük bilim adamları ve en büyük filozoflar da onu demeye çalışmışlar, ona yaklaşmaya yeltenmişlerdir. Şöyle de diyebiliriz: Kur'an'dan haberdar olmayan bir sanatçı, siyasal ve sosyal hiçbir etki altında kalmadan insanı ve çevreyi iyice araştırıp sonra da eserine aktarsa, ortaya çıkacak tablo Kur'an'a uyumsuz olmayacaktır. Işte fıtratın dili budur. Ama gelgelelim Müslüman bir sanatçı da Kur'an'ı okuyup hiçbir araştırma yapmadan ondan olduğu gibi bir film veya bir roman çıkarmaya kalkarsa, bir sanat eseri ortaya koyma başarısını asla yakalayamaz. Çünkü Kur'an insanlığın eline uzatılmış bir ipucudur. (Bu anlattıklarım yanlış anlaşılmasın. Bilim-din uyuşmasından bahsetmiyorum; fitrat-Kur'an meselesine değiniyorum.) Bütün bunlar olurken Mecidi'nin sinemasındaki manevi unsurlar gözümüzün içine sokularak değil kalbimize gizlice üflenerek veriliyor. (Çünkü sanat eserinde tebliğ değil telkin olur.)"(Çelik, 2010). 
Hakkı Uygur'la 2006'da yaptığı söyleşide Mecidi, filmlerinin müziğinde de fıtratla uygunluğu yakalamaya çalıştığını, kahramanın iç yolculuğunu destekleyen ve baskın olmayan enstrüman ve ritmi tercih ettiğini ifade eder. "Cennetin Çocukları son bir dakikalık heyecanlı koşu sahnesine dikkatinizi çekmek isterim. Klasik olarak baksak, bu sahnede heyecan artırıcı, aksiyon yüklü bir müzik kullanmamız gerekirdi... Ancak biz tam tersi müzik seçtik. Müzik burda kavramsal bir etki gösteriyor ve dışarıdaki karmaşayı değil Ali'nin içindeki hisleri anlatıyor." Bu sahnede kullandığı kesik şekilde çalınan üç telli sazın, orkestraların müziğinden çok daha etkili olduğunu da ekler. (Uygur, 2007, s. 102)

\section{Hz. Muhammed: Allah'ın Elçisi Filmi Mecidi Sinemasında Nerede Duruyor?}

Mustafa Akkad'ın 1977 yapımı, Anthony Queen'in de rol aldığı 'Çağrı' filminden sonraki bu en büyük bütçeli Muhammed Peygamber filmi, İran'la birlikte yurtdışındaki ilk gösterimini Kanada'da, Montreal Film Festivali'nde gerçekleştirmiştir. Türkiye'de gösterime girdiği ilk üç günde 183 bin 524 kişi tarafından izlenir. 2015'te Polonya'da Camerimage Uluslararası Film Festivali'nde "En İyi Yönetmen" ve "En İyi Görüntü Yönetmeni" ödüllerini alan film hem dinî tartışmaların hem de sinematografik eleştirilerin hedefi olur. Her zaman olduğu gibi sinematografik ya da sanatsal eleştiriler veya yorumların dinî, siyasî, ideolojik tartışmaların gölgesinde ve kısır kaldığı görülür. Sinemada özgün ve özgür çizgide kendisine ve temsil ettiği kültüre bir yer edinmeyi başaran Mecidi'nin, son filmi Hz Muhammed ile alışıldık tarzından ayrıldığını düşündüren veriler Tablo 1'de kategorize edilmeye çalışılmıştır. Kameraya ve müziğe dair değişimler ilk dikkati çekenlerdir ki bunlar daha ziyade teknolojinin son filmdeki hâkimiyetini göstermektedir. Sinemanın dili diye bahsedilen şey temelde bir anlatım aracı olarak görsel dili ve müziği ile zemin bulur (Soykan, 2009, s. 178). Bu anlamda bilhassa müzik yukarıdaki söyleşide kendi ifadelerinden kopmuş, orkestranın ihtişamlı gürültüsü fıtrî ahenk ritmine tercih edilmiştir. Zaman zaman kahramanın iç yolculuğunu paylaşan seyirci, ivmesi yüksek sahnelerde kameranın teknolojik baskınlığına yenilmiştir.

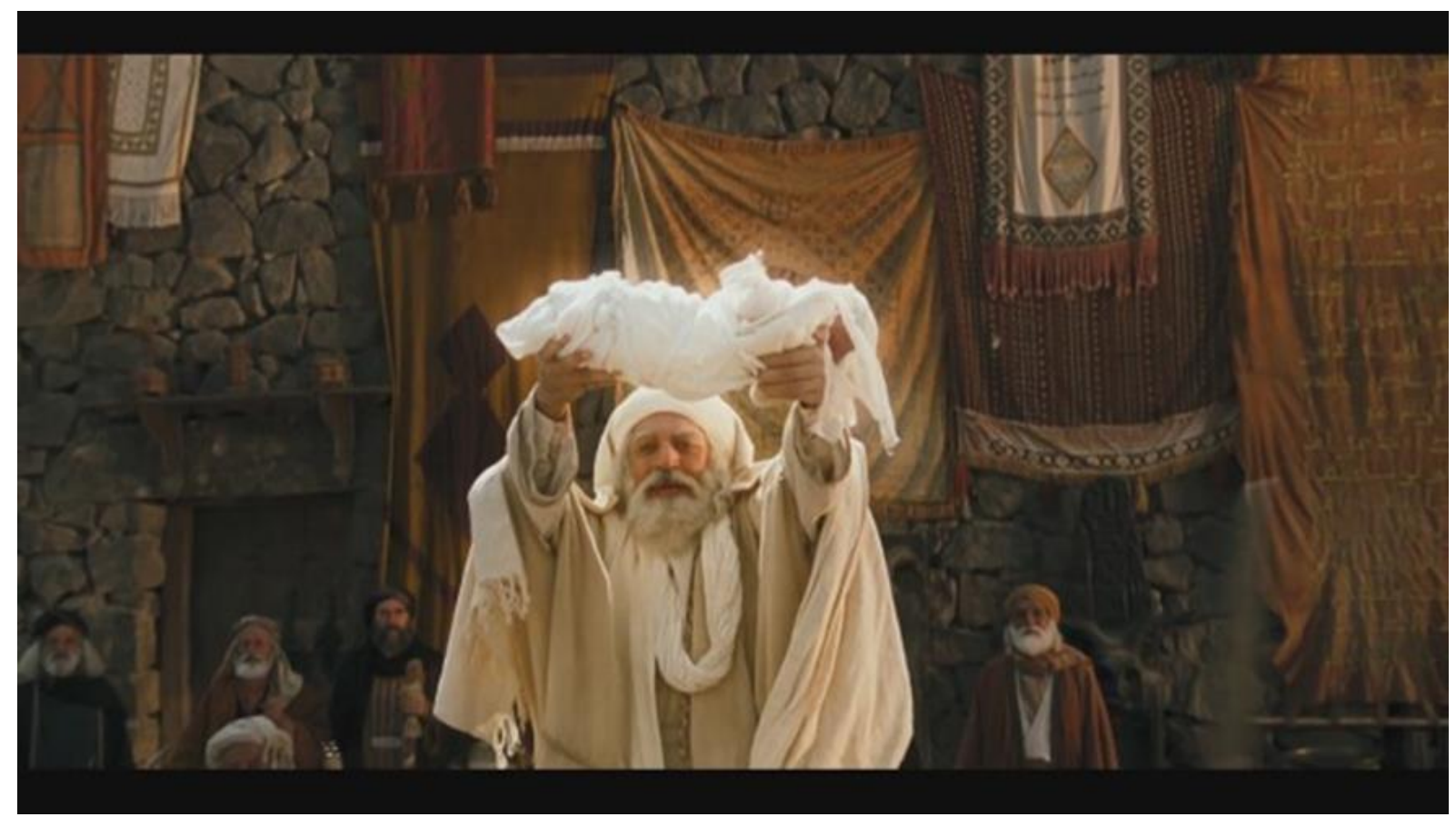

Görsel 4: Hz Muhammed: Allah'ın Elçisi filminden bir sahne... (Hz Muhammed: Allah'ın Elçisi)

Bütün bunlara rağmen özellikle anlatıdaki seyirciyi harekete geçirmeye tahrik etmek için açık ve sorgulayıcı üslûp Mecidi'nin sinemasını hâlâ eleştirel ve muhalif tarafta tutmaktadır. Senaryo ve diyalogların 
pasif seyirciyi, sorgulayan aktif özneler safına geçirmesi üçüncü sinema ya da yeni İtalyan gerçekliği çizgisinin devamı niteliğinde sayılabilir.

- "Kalpler iman ile dolup taşacaktır ama kimsenin düzenini bozmamak şartıyla"

- "Muhammed'in şehrin şanından ve şerefinden payına düşeni alması için Allah'ını kalbinde taşıması yeterli..."

- "Rabbimin benim şefaatime ihtiyacı yoktur. Ben sadece develerimin sahibiyim. Şehir ve Kâbe O'na aittir..........Bir sırrı var mı bilmem, ama bildiğim tek şey Kâbe'nin taştan yapıldığıdır."

- "Oysa günah, mazlumlara sırt çevirmenin adıdır."(Mecidi'nin Rahip Bahira'yaRasulullah'ın merhametine dair söylettiği replik.)

- Ey iman edenler! Allah için hakkı ayakta tutan, adaletle şahitlik eden kimseler olunuz. Bir topluluğa duyduğunuz kin, sizi âdil davranmamaya itmesin. Adaletli olunuz; bu takvânın ta kendisidir. Allah'a isyandan sakınınız. Allah yapmakta olduklarınızdan haberdardır.(Maide 8)(Kur'an-ı Kerim Meallerini Kıyasla , 2008)

Mecidi ticarî kaygıların ve sinemanın endüstrileşmesinin eleştirilerine bakışını, daha son filmi çekmeden önce 2006'daki bir söyleşide dile getirmiş; sinemanın, maddî giderleri çok fazla bir sanat olduğunu, ticarî açıdan kendi ayakları üstünde durabilmesi gerektiğini vurgulayarak, "Ben sinemanın endüstrileşmesi gerektiğini düşünenlerdenim; sinema, seyircilerin ödedikleri bilet paralarıla ayakta durabilmelidir." (Uygur, 2007, s. 95) sözleriyle ifade etmiştir. Dolayısıyla sinemanın endüstrileşmesini tam da özgürlüğünün teminatı olarak gördüğü söylenebilir.

Küreselleşmenin İran sineması üzerine etkilerine ise yine Dabaşi' nin gözüyle bakılırsa:

"Küreselleşme rüzgârına kapılan pek çok ülke gibi Iran da çok kritik bir yol ayrımında duruyor. Eski kuşak Iran sinemacılarının kendi yaratıcı egolarını toplumun kolektif bilincine dönüştürmeleri olarak biçimlendirdikleri sanatsal üretim biçimi, Iran sinemasının küresel çapta dikkatleri üzerine çekmesini sağladı. Kültürel sömürgecilik sürecinde öyle bir an gelmişti ki, kişisel olanın kurumsal olana dönüştüğü bu değişim olmadan, sömürgeciliğin kişiliksizleştirme politikalarına karşı yaratıcı bir direniş hareketi mümkün olmuyordu. Fakat kişisel olanın böylece kamusal olana dönüşmesi sürecinde, Üçüncü Dünya entelektüellerinin yerelci ve nativist (doğuştancı) doğası gizliydi....Son kuşak iran sinemacılarının temel çıkmazı, yaratıcılıkları nativist bir yorumla ortaya koyarak küresel çapta dikkat toplayabilmekte kullanmalarıydı." (Dabaşi H. , 2013 (2004), s. 280-281)

Dabaşi küreselleşmenin yaratıcılık üzerine olumsuz etkilerini söylediği yıl 2001'dir. Eski kuşak ve yeni kuşak İran sinemacıları mukayesesi de bu bağlamda anlaşılmalıdır. Dabaşi'nin bu yorumu üzerinden geçen on altı yılda Cannes, Venedik ve Locarno gibi festivalleri kontrol edenlerin teveccühünün, yerel ve egzotik bir nativist doğaya sahip İran sinemasını getirdiği noktayı bu zeminde incelemek, irdelemek önemlidir.

Tablo 1: Indian Fleers'in Battal Odabaş tarafından çevirilen tablosu ile Mecidi Sineması konumlandırılabilir: (Odabaş, 2013)

\begin{tabular}{|c|c|c|c|c|}
\hline & Birinci ve İkinci Sinema'da & Üçüncü Sinema'da & \multicolumn{2}{|c|}{ Mecidi Sineması } \\
\cline { 3 - 5 } & İşlev & İşlev & Eski & Son \\
& A & B & Filmleri & Filmi \\
\hline
\end{tabular}




\begin{tabular}{|c|c|c|c|c|}
\hline Anlatı & $\begin{array}{l}\text { Tam bir öyküyle izleyiciyi eğlendirmek } \\
\text { ve memnun etmek için kapalı anlatıya } \\
\text { odaklanır. }\end{array}$ & $\begin{array}{l}\text { Seyirciyi harekete geçirmeye tahrik } \\
\text { etmek için açık ve sorgulayıcı anlatı } \\
\text { tercih edilir. }\end{array}$ & B & B \\
\hline $\begin{array}{l}\text { Sessizlik } \\
\text { Kavramı }\end{array}$ & $\begin{array}{l}\text { Dramatik müzikler ve görüntüyü } \\
\text { destekleyen ses efektleri kullanılır. }\end{array}$ & $\begin{array}{l}\text { Sessizlik, görüntülerin izlenimini } \\
\text { destekleyerek boşlukları doldurmak için } \\
\text { seyirciyi davet eder ve ondan anlam } \\
\text { yaratmak için görüntüyle sessizliği } \\
\text { buluşturur. }\end{array}$ & B & A \\
\hline $\begin{array}{l}\text { "Kahraman" } \\
\text { Kavramı }\end{array}$ & $\begin{array}{l}\text { Bir bireyin öykünün akışı üzerinde } \\
\text { sağlayabildiği etkisini anlatma yoluyla } \\
\text { gerçekleştiren bir kimliktir. }\end{array}$ & $\begin{array}{l}\text { Kahramanın kahraman ayrıcalıkları } \\
\text { yoktur fakat öykünün gerekliliklerini } \\
\text { yerine getirir. }\end{array}$ & B & A \\
\hline Uzun Plan & $\begin{array}{l}\text { Kendinden ve doğadan varoluşsal } \\
\text { yabancılaşmayı ifade eder. }\end{array}$ & $\begin{array}{l}\text { İzleyicilerin telâşsız hayat ritminin } \\
\text { duygusuna dokunur ve bireysel } \\
\text { karakterleri bir ailesel, toplumsal ve } \\
\text { ulusal çerçeve içinde özerk olmayan } \\
\text { kuruluşlar olarak belirler. }\end{array}$ & B & B \\
\hline Çapraz Kurgu & $\begin{array}{l}\text { Antagonistleri arasında pozitif ve } \\
\text { negatif kutup sunar. }\end{array}$ & $\begin{array}{l}\text { İdeolojilerin çatışmasını } \\
\text { aydınlatmaktadır. }\end{array}$ & B & B \\
\hline Yakın Çekim & $\begin{array}{l}\text { Karakterin bireysel psikolojisini } \\
\text { vurgular. }\end{array}$ & $\begin{array}{l}\text { Seyrek kullanılır, çünkü doğal olmayan } \\
\text { bir görünümü vardır. }\end{array}$ & B & A \\
\hline $\begin{array}{l}\text { Çevrinmeli } \\
\text { Çekim }\end{array}$ & $\begin{array}{l}\text { Bazan } 180 \text { derece kuralına göre } \\
\text { mekânsızlığı vurgulamak ya da } \\
\text { kaybolmak duygusunu yaratmak için } \\
\text { kullanılır. }\end{array}$ & $\begin{array}{l}\text { Zaman zaman kullanılır. Üçüncü } \\
\text { Dünyanın geniş mekânını anlatmak için } \\
180 \text { derece kuralı terk edilir. }\end{array}$ & B & A \\
\hline Aydınlatma & $\begin{array}{l}\text { Dramada atmosferik aydınlatma, } \\
\text { yüksek kontras ve düşük ton kullanılır. }\end{array}$ & $\begin{array}{l}\text { Işığın doğal kullanımı vurgulayarak daha } \\
\text { az aydınlatma kuralı geçerlidir. }\end{array}$ & B & A \\
\hline Kamera Açısı & $\begin{array}{l}\text { Doğal bir perspektif için göz hizası } \\
\text { çekimleri genellikle estetik bakış açısı } \\
\text { için kullanılır. }\end{array}$ & $\begin{array}{l}\text { Karakterler/durumlar arasında } \\
\text { tahakküm ve güç göstermek için ve } \\
\text { siyasal ya da toplumsal yorumlar için } \\
\text { düşük ya da yüksek açıların kullanııı. }\end{array}$ & B & B \\
\hline $\begin{array}{l}\text { Kamera } \\
\text { Yerleşimi }\end{array}$ & $\begin{array}{l}\text { Kamera uzaklığı, yakın planla sunulan } \\
\text { sahnenin duygusuna bağlıdır. }\end{array}$ & $\begin{array}{l}\text { Psikolojik gerçekliğe yapılan küçük } \\
\text { vurgu; yakın plânların minimal kullanılır. }\end{array}$ & B & A \\
\hline $\begin{array}{l}\text { Kamera } \\
\text { Hareketi }\end{array}$ & $\begin{array}{l}\text { Çoğunlukla sabit perspektif; anlam için } \\
\text { birey ile gösterim ve hareket tercih } \\
\text { edilir. }\end{array}$ & $\begin{array}{l}\text { Afrika filmleri; genellikle sabit } \\
\text { perspektiflidir. Latin Amerikan filmleri; } \\
\text { genellikle taşınabilir kamera } \\
\text { deneyimsel katılımı ve dramatik kimliği } \\
\text { teşvik etmek için genellikle el } \\
\text { kamerasıdır. }\end{array}$ & B & A \\
\hline Set Düzeni & $\begin{array}{l}\text { Stüdyo ortamı, yönlendirici } \\
\text { denetimlerdir. }\end{array}$ & $\begin{array}{l}\text { Filmin gerçekliğini artırmak için yerinde } \\
\text { oluşturulan set kullanılır. }\end{array}$ & B & A \\
\hline Oyun & Tanınmış oyuncu vardır. & $\begin{array}{l}\text { Gerçek hayat rollerinde genellikle } \\
\text { oyuncu yoktur. }\end{array}$ & B & A \\
\hline Paralel Kurgu & $\begin{array}{l}\text { Genellikle oyuncu ve kamera arasında } \\
\text { doğrudan bir bağlantı yoktur. }\end{array}$ & $\begin{array}{l}\text { Bazen, oyuncu kamera /seyirciye doğru } \\
\text { döner ve sözlü anlatıya geçer. }\end{array}$ & B & A \\
\hline
\end{tabular}

\section{Sonuç}

Nitel araştırma yöntemleri kullanılarak yapılan bu çalışmada sinemaya kültür çalışmaları literatürü taranmak suretiyle bakılmış, üzerine en çok yazılmış Mecidi filmleri yorumlanarak çalışmayı destekleyen anlamlı sonuçlar aranmıştır. 
Bu çalışmanın temel amacı, kültürel bir çalışma alanı olarak genelde sinema özelde İranlı yönetmen Mecid Mecidi sinemasının yeni ve özgün bir dil kurduğu ve son fimi $\mathrm{Hz}$ Muhammed'de sosyal içerikte özgün dilini muhafaza etmekle birlikte, batıya mesaj verme kaygısının teknik, müzik ve görsel açılardan özgünlüğünü Hollywood lehine yitirdiği görüşüne cevap aramaktı.

Literatüründen de gördüğümüz gibi İmgesel ve belgesel sinemanın dönüşerek mevcut teknolojiyi kullanması, Üçüncü Sinemayı da etkilemiştir. Yeni tanımlar ve kavramların içinde Mecidi Sineması'nın da bu dönüşümden nasibini aldığını; lâkin teknoloji ile birlikte "fıtratın dili" ile sinema yaptığı iddiasının kısmen film endüstrisi ve bu endüstrinin baş temsilcisi Hollywood lehine zayıfladığı söylenebilir. Walter Benjamin'in dediği gibi tekniğin yeniden üretilebildiği çağda sanat yapıtı artık 19. yüzyıl öncesi anlamını kaybetmiş, emekten soyutlanmıştır (Benjamin, 2013).

Burada dikkat edilmesi gereken önemli bir nokta, Üçüncü Sinema bir sınıflandırma ve değerlendirme ölçütü olarak kullanılması, "ötekileştiren" bir tanım olması, bu tanım içinde değerlendirilen ülkelerin hayalî ve aldatıcı bir çatı altında toplamak suretiyle tarihî, coğrafî, kültürel ve toplumsal farklılıkların kayda değer görülmemesi gibi pek çok nedenle eleştirilmektedir. Bu politik söyleme dayalı kavramlar; İran Sineması'nın uluslararası alanda kabul görmesinin "oryantalizm"in etkisinin olup olmadığı; Dabaşi'nin bahsettiği küreselleşmenin tehlikeli ama bir yandan da özgürleştirici etkileri gibi sorgulamalar ise bir başka çalışmada ele alınabilir. Bu anlamda, daha sonra yapılacak olan çalışmalarda bu noktanın dikkate alınmasında yarar görülmektedir. Tüm bu değerlendirme ve yorumlar yapılırken, kuşkusuz bu çalışmanın yetersiz bir çalışma olduğunu ve neden-sonuç ilişkisi çıkartılamayacağını unutmamak gerekir. Ancak, elde edilen ipuçları ile daha sonraki çalışmalarda İngilizce ve Farsça literatürün de taranmasıyla konu derinleştirilebilir. Bununla birlikte, elde edilen bulgular, sinemada özgün bir dilin geliştirilmesi ve kültür çalışmalarında sinemanın önemine dikkat çekmesi açııından önemlidir. Zaman konusunda yeterli bir çalışma sürecinin olmaması da dâhil belirtilen bu sınırlılıklar göz önünde bulundurulduğunda, araştırmadan elde edilen sonuçları yeterli görmek doğru bir yaklaşım olmayacaktır.

\section{Kaynakça}

Adorno, T. W. (2016). Kültür Endüstrisi Kültür Yönetimi (10 b.). (N. Ü. Elçin Gen, Çev.) İstanbul: iletişim. Aristotales. (2011). Poetika (5 b.). (S. Rifat, Çev.) İstanbul: Can.

Armes, R. (2011). Ü̧̧üncü Dünya Sineması ve Batı. (B. Kaya, Çev.) Doruk.

Bağdatlı, S. (2000). Italyan Yenigerçekliği. ìstanbul: Der.

Bazin, A. (1995). Çağdaş Sinemanın Sorunları. Ankara: Bilgi.

Bekiroğlu, N. (2010). Baran: Fıtratın Dili. Aralık 25, 2016 tarihinde Fakirane: http://www.fakirane.org/ adresinden alındı

Benjamin, W. (2013). Fotoğrafın Kısa Tarihi-Teknik Araçlarla Yeniden Üretim (Çoğaltma) Çağında Sanat Eseri. İstanbul: Agora Kitaplığı.

Biraz da Felsefe. (tarih yok). Ocak 8, 2017 tarihinde Dipnot: http://www.dipnotkitap.net. adresinden alındı

Çelik, M. (2010, Temmuz-Ağustos). Bir Sinema Yönetmeni Olarak Mecid Mecidi ve Onun Özgün Sanat Dilinde İnsan. Şehrengiz Dergisi(5).

Dabaşi, H. (2006). Filistin Sineması: Bir Ulusun Hayalleri. (O. Akınbay, Çev.) İstanbul: Agora.

Dabaşi, H. (2013 (2004)). İran Sineması (2 b.). (B. K. Barış Aladağ, Çev.) ìstanbul: Agora.

Enzensberger, H. M. (1980). Bir Kitle Iletişim Araçları Teorisinin Oluşturucu Öğeleri. İstanbul: Birikim.

Esra Biryıldız, Z. Ç. (2007). Üçüncü Sinema ve Üçüncü Dünya Sineması. İstanbul: Es.

Film Arası. (2016, Mart). Ortadoğu Sinemasında Kadın Olmak. İstanbul: Film Arası. 
Hz Muhammed: Allah'ın Elçisi. (tarih yok). Aralık 22, 2016 tarihinde Film Expresi: http://www.filmexpresi.com. adresinden alındı

Iran Sineması'na Giriş: En Özel 15 Iran Filmi. (2014, Eylül 12). Aralık 13, 2016 tarihinde Sinematopya: http://www.sinematopya.com.tr adresinden alındı

Kanat, F. (2007). Iran Sinemasında Kadın. Ankara: Dipnot.

Kaynar, H. (2012). Projesiz Modernleşme: Cumhuriyet İstanbulu'ndan Gündelik. İstanbul: İstanbul Araştırma Enstitüsü.

Kur'an-ı Kerim Meallerini Kıyasla . (2008). Aralık 21, 2016 tarihinde http://www.kuranmeali.org/ adresinden alındı

Odabaş, B. (2013). Üçüncü Sinema. İstanbul: Agora.

Olgun, C. K. (2008, Eylül-Ekim-Kasım). "Gerçeklik ve Gölgesi": Sanat ve Anlama. Sosyoloji Notları, 45-50.

Özbek, M. (2013). Popüler Kültür ve Orhan Gencebay Arabeski (13 b.). istanbul: İletişim.

Özen, E. (2009). Geçmişe Bakmak. Kebikeç(27), 131-156.

Özvaran, Ç. (2015, Kasım-Aralık). Sinema ya da Ayna. Karabatak, 84-85.

Sever, N. (2009). Sanat Sosyolojisi. (Ö. N. Soykan, Dü.) İstanbul: Dönence.

Soykan, Ö. N. (Dü.). (2009). Sanat Sosyolojisi. İstanbul: Dönence.

Tatar, U. (2012, Temmuz 18). Sinemanın Tarihsel Gelişimine Kısa Bir Bakış. Aralık 13, 2016 tarihinde Maksat Sinema Olsun: http://www.maksatsinema.com.tr adresinden alındı

Turner, G. (2016). Ingiliz Kültürel Çalışmaları (1 b.). (B. Ö. Deniz Özçetin, Çev.) Ankara: Heretik.

Uygur, H. (2007, Eylül). Türkiye Söyleşileri 2. Sanatın amacı insanı yüceltmektir: Mecid Mecidi. İstanbul: Küre. 